\title{
EKSPLORASI ETNOMATEMATIKA PADA PROSES PRODUKSI GULA KELAPA DI DESA KLESEM KEBONAGUNG PACITAN
}

\author{
Mulyadi \\ STKIP PGRI Pacitan \\ * Corresponding Author Email: mulyadipacitan@gmail.com \\ Received: 1 Maret 2020; Revised: 27 Maret 2020; Accepted: 30 Maret 2020
}

\begin{abstract}
ABSTRAK
Fenomena penting dalam kajian matematika dan budaya penting untuk di eksplore melalui etnomatematika sebagai sumber pengetahuan yang kontekstual untuk memahami aktivitas matematika dilingkungan dan dikehidupan sehari-hari. Tujuan penelitian ini untuk mengetahui: (1) konsep-konsep matematika, (2) nilai-nilai karakter, dan (3) kontribusi etnomatematika pada proses produksi gula kelapa terhadap pendidikan matematika. Jenis penelitian ini adalah penelitian kualitatif. Metodenya adalah deskriptif dengan pendekatan etnografi dan studi kasus. Subjek pada penelitian ini adalah pelaku produksi gula kelapa. Pengumpulan data dengan metode observasi, wawancara, studi pustaka dan dokumentasi. Uji keabsahan data menggunakan triangulasi teknik dan sumber. Teknik analisis data menggunakan model Miles dan Huberman yakni reduksi data, penyajian data, dan verifikasi atau kesimpulan. Hasil penelitian ini adalah: (1) Konsep-konsep matematika yang terdapat pada proses produksi gula kelapa di antaranya geometri bidang, geometri ruang, perbandingan, kesebangunan, serta aritmatika sosial; (2) nilainilai karakternya yaitu sabar, telaten, terampil, kerja keras, serta semangat yang tinggi; sedangkan (3) kontribusi etnomatematikanya adalah memberikan pemahaman siswa mengenai konsep-konsep matematika teoritis dengan kondisi sosial budaya di masyarakat, memanfaatkan konsep matematika pada proses produksi gula kelapa menjadi materi sebagai bahan pembelajaran matematika, memanfaatan fenomena budaya kearifan lokal dengan tujuan untuk mengenalkan konsep-konsep matematika dan pendidikan karakter.
\end{abstract}

Kata kunci: Etnomatematika, gula kelapa, konsep, karakter

\section{ABSTRACT}

Critical phenomena in mathematics related to culture are essential to be explored through ethnomathematics as a contextual knowledge to understand mathematical activities in daily life. The research aims to determine mathematical concepts, character values, and the contribution of ethnomathematics to the process of producing coconut sugar for mathematics education. The researcher used qualitative research. The method is descriptive with an ethnographic approach and case studies. The subject was coconut sugar farmers. Data was collected by implementing observation, interviews, literature study, and documentation. The researcher used triangulation techniques and sources as data validity testing. In analyzing the data, the researcher used Miles and Huberman model, including data reduction, data presentation, and verification or conclusions. This study resulted in three findings. First, mathematical concepts were found in the process of coconut sugar production, including field geometry, spatial geometry, comparison, congruence, and social arithmetic. Second, the character values are patience, meticulous, skilled, hard work, and high spirits. Third, the contribution of ethnomathematics is providing students with an understanding of theoretical mathematical concepts with socio-cultural conditions, utilizing mathematical concepts in the process of producing palm sugar as source for learning mathematics, utilizing local wisdom cultural phenomena to introduce mathematics concepts and character education.

Keywords: Ethnomatematics, coconut sugar, concepts, character

How to Cite: Mulyadi. (2020). Eksplorasi Etnomatematika Pada Proses Produksi Gula Kelapa Di Desa Klesem, Kebonagung, Pacitan, 4(1), $163 \quad-\quad 176$, doi: http://dx.doi.org/10.31100/histogram.v4i1.582

Permalink/DOI: http://dx.doi.org/10.31100/histogram.v4i1.582

Copyright $@$ 2020, THE AUTHOR (S). This article distributed under the CC-BY-SA-license. 


\section{PENDAHULUAN}

Aktivitas sehari-hari pada proses kehidupan manusia tidak lepas dari matematika dan masyarakat telah banyak menerapkan konsep-konsep matematika. Tanpa mempelajari konsep-konsep matematika secara khusus, tetapi masyarakat telah menerapkan konsep tersebut dalam aktivitas kehidupan sehari-hari (Rachmawati, 2012). Konsep-konsep matematika yang ada dalam kehidupan masyarakat dapat dikontruksi sebagai pengetahuan yang mempelajari matematika dan budaya. Dikenal dalam pengetahuan dengan etnomatematika. Istilah etnomatematika digagas oleh Ubiratan D'Ambrosio, seorang matematikawan Brazil pada tahun 1977.

Ethnomathematics is "the mathematics which is practiced among identifiable cultural groups such as national-tribe societies, labor groups, children of certain age brackets and professional classes". So this practiced mathematics of cultural groups can be different from its well-known and recognized form, which is defined by ethnomathematicians as eurocentricmathematic." (Ubiratan D'ambrosio, 1985).

Artinya bahwa etnomatematika itu adalah matematika yang dipakai di kelompok budaya tertentu, kelompok masyarakat dan lain-lain yang prakteknya bisa berbeda-beda dimasing-masing kelompok tersebut. Disisi lain (Nuh \& Dardiri, 2017) mengatakan bahwa berbagai aktivitas matematika berikut merupakan etnomatematika yang menggunakan konsep matematika secara luas, diantaranya aktivitas berhitung, merancang bangunan atau alat, mengelompokkan, mengukur, bermain, menentukan lokasi dan sebagainya

Kabupaten Pacitan adalah wilayah penghasil kelapa terbesar kedua di Jawa Timur setelah Kabupaten Banyuwangi. Aktivitas dalam pengolahan kelapa beraneka ragam, salah satunya adalah pembuatan/produksi gula merah. Gula kelapa atau juga sering disebut gula merah merupakan pemanis rasa untuk bahan minuman dan bahan pangan yang berasal dari olahan nira kelapa. Gula merah ini biasanya diperdagangkan dalam bentuk bongkahan padat dengan beraneka macam bentuk bangun geometri, tergantung dari wadah yang digunakan untuk mencetak. 
Gula merah dapat dikonsumsi sebagai bumbu sedap rasa makanan, bahan pemanis minuman layaknya bahan pemanis lain yakni gula aren, gula pasir, dan lain sebagainya. Gula jenis ini juga dapat digunakan untuk bahan baku pada kegiatan industri olahan jamu, olahan pangan dan berbagai minuman instan.

Proses produksi gula merah tidak lepas dari aktivitas - aktivitas matematika. Aktivitas produksi tersebut diantaranya proses penyadapan nira kelapa, pengolahan nira kelapa, pencetakan gula kelapa, dan proses jual beli hasil produksi. Pertama, pada proses penyadapan nira kelapa, dilakukan pemotongan terhadap bunga kelapa supaya nira yang terkandung di dalamnya bisa keluar. Kemudian air nira tersebut diwadahi tempat khusus yang dinamakan bumbung (dari bahan bambu) atau terkadang ada alternatif lain memakai botol/jligen. Pada proses ini jelas sekali menggunakan aplikasi konsep matematika yakni pada berapa kali minimal dilakukan pemotongan atau pengirisan pada bunga kelapa agar air niranya bisa keluar setiap harinya. Jumlah waktu yang dibutuhkan jika jarak dan ketinggian pohon kelapa berbeda-beda. Model geometri wadah air nira juga tak lepas dari konsep matematika, dan lain-lain. Kedua, pada proses pengolahan nira membutuhkan waktu yang cukup lama. Hal ini tergantung dari banyak sedikitnya nira kelapa yang diolah serta besar kecilnya nyala api yang digunakan selama proses pengolahan. Selain waktu, banyaknya kayu bakar yang diperlukan juga sangat bergantung dari banyak sedikitnya nira yang diolah dan lamanya proses pemasakan nira. Banyaknya gula kelapa yang dihasilkan juga bergantung dari banyaknya air nira sebelum diolah. Besar kecilnya wadah yang dipakai untuk memasak air nira juga berpengaruh terhadap kecepatan produksi. Hal ini jika dikaitkan dengan matematika di sekolah maka akan membentuk wawasan baru yang kontekstual dengan kehidupan nyata. Pada konsep ini jelas terdapat konsep perbandingan dan geometri. Ketiga, pencetakan gula kelapa menggunakan alat cetak yang bentuknya berbeda-beda, tergantung keinginan produsen. Karena pola bentuk cetakan gula tersebut juga mempengaruhi harga gula. Sehingga dalam tahap ini pelaku usaha secara tidak langsung memahami konsep matematika tentang bagaimana cara mendapatkan hasil yang banyak melalui bentuk cetakan. Keempat, proses jual beli yang tentu juga tak lepas dari 
konsep matematika peluang bagaimana supaya mendapatkan sasaran pasar yang baik dan keuntungan yang besar.

Penjelasan konsep pada proses produksi gula kelapa diatas menunjukkan bahwa betapa pentingnya memahami konsep matematika dalam aktivitas seharihari. Apalagi jika diterapkan dalam pembejaran disekolah. (Mulyadi \& Cahyani, 2017) menyatakan bahwa mayoritas kendala dalam pembelajaran adalah karena tidak memahami konsep. Memahami konsep matematika adalah hal yang mendasar utamanya bagi siswa karena ini menjadi dasar pondasi dalam membentuk konsepsi. Sehingga dalam pembangunan pemahaman siswa kedepan dapat membentuk konsepsi yang benar.

Kerangka proses tersebut konsep matematika yang dikaji pada penelitian ini diantaranya konsep geometri, konsep perbandingan senilai, konsep perbandingan jarak, waktu, dan kecepatan, konsep peluang, konsep perolehan laba rugi, dan lain-lain. Geometri merupakan materi mendasar yang wajib diperoleh siswa disekolah. Banyak konsep-konsep geometri yang sangat penting dimiliki oleh siswa dalam upaya membangun konsepsi abstrak yang mendasar dari hal-hal yang bersifat spasial dan visual, contohnya bidang, pengukuran, pola dan pemetaan. Sedangkan apabila dilihat dari sudut pandang matematika Abdussakir (Ikhsan \& Juandi, 2015) mengatakan bahwa geometri menyediakan pendekatanpendekatan sebagai upaya untuk memecahkan masalah melalui gambar visual, sistem koordinat, diagram, transformasi dan vektor.

Geometri merupakan bagian dari ilmu yang membahas tentang hubungan antara titik, garis, sudut, bidang dan bangun ruang. Geometri dapat dikategorikan menjadi 2 (dua) macam, yakni geometri datar (bangun datar) dan geometri ruang (bangun ruang). Geometri datar adalah geometri yang bersifat 2 (dua) dimensi sedangkan geometri ruang adalah geometri yang bersifat 3 (tiga) dimensi. Geometri 2 (dua) dimensi meliputi: Bujur sangkar, Segitiga, Belah ketupat, Persegi panjang, Jajaran genjang, Trapezoid, Trapesium, Heksagon, Pentagon, Oktagon, Heptagon, Lingkaran. Geometri 3 (tiga) dimensi meliputi: Bola, Kubus, Kuboid, Kerucut, Silinder/tabung, Prisma, Limas/piramida. Geometri yang 
terdapat pada proses produksi gula kelapa dapat dilihat dari bentuk gula kelapa yang dihasilkan yang berbentuk setengah lingkaran dan silinder.

Perbandingan senilai, perbandingan jarak, waktu dan kecepatan merupakan perbandingan dari dua atau lebih besaran yang mana ketika suatu variabel bertambah, maka variabel yang lain pun ikut bertambah juga. Contoh kasus pada kehidupan sehari-hari yang berupa perbandingan senilai adalah (1) banyak barang dengan jumlah harga barang, (2) jumlah tabungan dengan waktu penyimpanan dan (3) jumlah pekerja dengan jumlah upah. Konsep perbandingan senilai yang terdapat pada produksi gula kelapa dapat dilihat dari (1) Lama waktu yang digunakan untuk mengolah nira menjadi gula kelapa bergantung dari banyak sedikitnya nira yang dimasak, (2) banyak sedikitnya gula kelapa yang diperoleh bergantung pada banyak sedikitnya nira yang diolah dan (3) banyak sedikitnya kayu bakar yang digunakan tergantung dari banyak sedikitnya nira yang diolah, dan lain-lain.

Laba atau rugi adalah selisih antara jumlah nilai yang dihasilkan dengan jumlah nilai yang dikeluarkan. Laba merupakan keuntungan yang diperoleh dari suatu hasil produksi, baik perseorangan maupun perusahaan ketika kondidi nilai yang dihasilkan lebih besar dibandingkan dengan nilai yang dikeluarkan. Sedangkan rugi menunjukkan keadaan dimana biaya produksi lebih besar daripada harga jual. Dalam kondisi ini konsep perhitungan laba rugi tentunya juga tak lepas dari pemahaman konsep peluang harga dan peluang pasar. Sehingga analisa proses produksi harus detail supaya peluang-peluang yang ada dapat dijadikan kekuatan mendapatkan keuntungan yang sebesar-besarnya.

Manusia adalah makluk sosial yang tak bisa hidup sendiri. Pada kehidupanya pun untuk bisa bertahan dan beradaptasi dengan baik membutuhkan nilai-nilai, norma-norma, agama, budaya dan karakter. Berkaitan dengan eksplorasi etnomatematika yang dilakukan dalam penelitian ini adalah mengidentifikasi nilai-nilai karakter pada proses produksi gula kelapa. Nilai merupakan sifat-sifat yang penting dan bermanfaat bagi kemanusiaan. Dan karakter merupakan akhlak, sifat kejiwaan, budi pekerti yang menjadi ciri khas seseorang. Sedangkan pendidikan karakter merupakan suatu konsep dasar 
pemikiran seseorang agar lebih berarti dari sebelumnya baik dari segi akhlak, jasmani, rohani maupun budi pekerti sehingga dapat diharapkan mengantisipasi adanya krisis moral. Karakter memiliki peranan yang sagat penting dalam berbagai aspek kehidupan, bermasyarakat, beragama, berbangsa, dan bernegara.

Bukti nyata bahwa pembangunan karakter adalah hal yang sangat penting bagi kehidupan manusia telah disadari oleh pemerintah melalui terbitnya Undangundang Nomor 17 tahun 2007 tentang Rencana Pembangunan Jangka Panjang Nasional (RPJPN) 2005-2025. Pemerintah memiliki tekad kuat dalam membangun karakter bangsa pada setiap bidang, khususnya di bidang pendidikan. Karena pendidikan adalah media atau wadah yang cukup efektif untuk membentuk karakter seseorang. Memberikan wawasan dan pengetahuan nilai karakter pada peserta didik melalui dari pelaku usaha olahan gula kelapa tentu menjadi hal yang menarik. Karena kontekstul dengan kehidupan, dan diharapkan dapat memberikan inspirasi yang baik. Banyak nilai-nilai karakter dan pengetahuan yang dapat diambil dari proses produksi gula kelapa.

Etnomatematika dalam kehidupan masyarakat tentu memiliki kontribusi pada pendidikan matematika. Salah satunya dengan memahami konsep-konsep matematika dan nilai-nilai karakter yang ada pada fenomena etnomatematika proses produksi gula kelapa dapat memberikan wawasan bagi peserta didik. Selain itu dapat menjadi rancangan pembelajaran berbasis kearifan lokal. Serta mengajarkan pendidikan karakter yang baik bagi anak-anak sekolah.

Mengingat pentingnya menindaklanjuti kajian di atas, maka penulis tergerak melakukan penelitian tentang etnomatematika yang terdapat pada proses produksi/pengolahan gula kelapa dalam rangka melakukan eksplorasi kajian keilmuan untuk menggali dan mengidentifikasi konsep-konsep matematika, nilai - nilai karakter dan kontribusi etnomatematika pada proses produksi gula kelapa terhadap pendidikan matematika.

\section{METODE PENELITIAN}

Penelitian ini akan dilaksanakan di Kabupaten Pacitan pada bulan Oktober - Desember 2019. Jenis penelitian ini adalah penelitian kualitatif. Metode yang digunakan penulis adalah deskriptif dengan pendekatan etnografi dan studi kasus. 
Subyek yang digunakan dalam penelitian ini adalah masyarakat pelaku penyadap nira dan pemroduksi gula kelapa di Desa Klesem Kecamatan Kebonagung Kabupaten Pacitan. Teknik pengambilan subyek pada penelitian ini adalah purposive sampling dan model ini dikatakan lebih cocok digunakan untuk penelitian kualitatif atau penelitian yang tidak melakukan generalisasi (Sugiyono, 2014). Sumber data pada penelitian ini adalah penyadap nira dan pengolah nira/pemroduksi gula kelapa. Obyek yang diteliti pada penelitian ini adalah konsep-konsep matematika yang terdapat pada proses produksi gula kelapa, nilainilai karakter, serta kontribusi etnomatematika yang terdapat pada proses produksi gula kelapa terhadap pendidikan matematika.

Instrumen pengumpulan data dengan metode observasi, wawancara, studi pustaka dan dokumentasi (rekaman audio visual, foto dan dokumen lain). Uji Validitas instrumen dilakukan dengan content validity oleh experts judgment. Observasi dilakukan oleh peneliti dengan cara mengamati kegiatan yang dilakukan oleh subyek penelitian. Data yang akan diungkapkan adalah data tentang konsep-konsep matematika yang terdapat pada proses produksi gula kelapa. Hasil wawancara akan digunakan ketika memperdalam hasil komparasi data penelitian. Uji keabsahan data penelitian ini menggunakan triangulasi. Triangulasi yang digunakan pada penelitian ini adalah triangulasi teknik dan sumber untuk memastikan bahwa data yang didapat adalah valid. Teknik analisis data menggunakan teori Miles dan Huberman yang meliputi data reduction, data display, dan conclusion drawing/verification. Aktivitas-aktivitas pada analisis data kualitatif dilakukan secara interaktif dan berlangsung secara terus menerus hingga tuntas, serta datanya mencapai jenuh (Sugiyono, 2014).

\section{HASIL DAN PEMBAHASAN}

\section{A. Hasil Penelitian}

Berdasarkan hasil observasi, wawancara, studi pustaka dan dokumentasi diperoleh data-data dan informasi penelitian sebagai berikut. Observasi langsung dilakukan terhadap para pelaku usaha produksi gula kelapa di Desa Klesem Kecamatan Kebonagung Kabupaten Pacitan. Mayoritas masyarakat desa tersebut mata pencaharian utamanya adalah bertani, berkebun dan nelayan. Sembari 
melakukan pekerjaanya, setiap hari pada pagi dan sore di Desa Klesem pasti dijumpai penderes. Penderes adalah orang yang melakukan aktivitas pengambilan air nila dari pohon kelapa. Rata-rata penderes adalah dari kalangan pria dan ibu rumah tangganya bertugas untuk melakukan produksi gula.

Etnomatematika pada proses produksi gula kelapa dapat di eksplore berdasarkan identifikasi alat dan bahan serta aktivitas-aktivitas yang ada dalam proses tersebut. Berikut adalah bentuk geometri bangun datar dan bangun ruang peralatan produksi gula kelapa. Diantaranya adalah Pisau/Belati, Eklek, Bumbung, Panci/kuali, Kalo (saringan), Irus, Tungku, Cetakan, Dingklik/tempat duduk, Ember, Kerokan/Sendok, dan lain-lain.

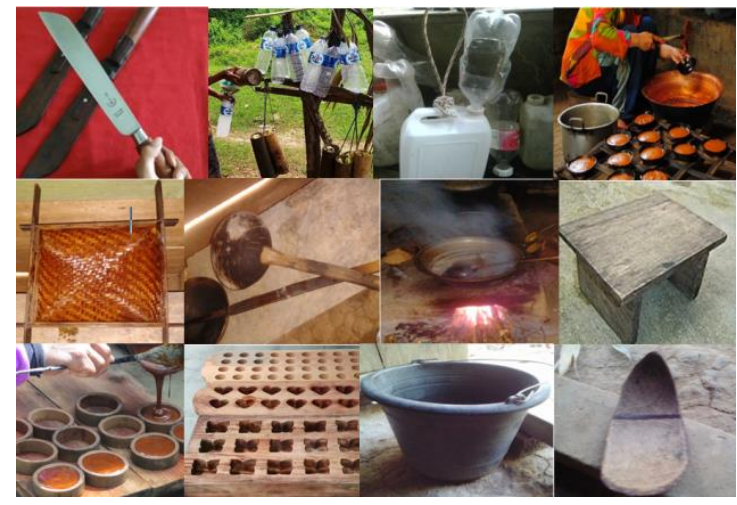

\section{Gambar 1. Alat dan Bahan Produksi Gula Kelapa}

Dilihat dari gambar 1. tampak bahwa alat dan bahan produksi gula kelapa tersebut memiliki bentuk dan fungsi masing-masing. Dalam proses produksi gula kelapa dapat dilakukan identifikasi konsep geometri alat dan bahan serta konsepkonsep matematika lain dalam aktivitas produksi. Konsep matematika pada proses penyadapan nira kelapa dapat diidentifikasi sebagai berikut: (1) konsep geometri pada (bumbung) wadah untuk menampung nira yang berasal dari bambu, botol dan jligen; (2) konsep perbandingan waktu, jarak dan kecepatan pada kondisi jarak antar pohon kelapa dan ketinggian pohon kelapa yang berbeda-beda; (3) konsep pemotongan/pengirisan bunga kelapa (manggar) supaya air niranya keluar setiap hari pada pagi dan sore hari; (4) konsep perhitungan supaya manggar pada pohon kelapa tidak cepat habis dan dapat mengasilkan air nira sebanyakbanyaknya dalam waktu yang lama. 
Konsep matematika pada proses pengolahan nira menjadi gula kelapa, yaitu: (1) perbandingan senilai antara banyak sedikitnya nira dan waktu yang dibutuhkan selama proses pemasakan air nira menjadi gula kelapa; (2) Perbandingan senilai antara banyak sedikitnya nira yang dimasak dengan gula kelapa yang dihasilkan; (3) konsep geometrid an ukuran pada saat menuangkan air nira pada wadah/panci dan menuangkan hasil gula kelapa kedalam berbagai bentuk cetakan; (4) konsep rotasi pada aktivitas pengadukan nira menjadi gula kelapa; (5) konsep ukuran pada nyala api yang digunakan untuk memasak nira menjadi gula kelapa; (6) konsep perhitungan banyaknya kayu bakar yang diperlukan karena hal ini sangat bergantung pada banyak sedikitnya air nira yang diolah dan lamanya proses pemasakan; (7) konsep perbandingan waktu karena besar kecilnya wadah/panci dan nyala api yang dipakai untuk memasak air nira juga berpengaruh terhadap kecepatan produksi.

Konsep matematika pada proses pencetakan dan penjualan gula kelapa, yaitu: (1) konsep geometri cetakan; (2) konsep perbandingan, karena bentuk cetakan gula kan mempengaruhi harga gula; (3) konsep perhitungan dan analisa laba rugi; (4) konsep peluang pasar dan perbandingan harga pesaing; (5) konsep aritmetika; (6) konsep kesebangunan cetakan gula kelapa. Konsep matematika ekonomi dalam proses ini sangat menentukan keberhasilan usaha. Karena dalam manajemen keuangan yang meliputi harga kayu bakar yang dibutuhkan selama proses pengolahan nira, harga cetakan untuk mencetak gula kelapa, serta penentuan harga jual dari gula kelapa membutuhkan pengetahuan yang baik agar mendapatkan laba yang sesuai.

Kajian etnomatematika pada proses produksi gula kelapa memiliki peranan penting dalam pendidikan matematika karena kontekstual dengan materi dan dapat membentuk karakter siswa. Selain itu juga dapat dijadikan sebagai sumber pembelajaran bagi siswa di sekolah yang berbasis kearifan lokal. Nilai-nilai karakter yang dapat dikembangkan melalui proses penyadapan nira, proses produksi dan proses penjualan gula kelapa antara lain ketelatenan, kesabaran, kedisiplinan, keuletan, semangat yang tinggi dan bekerja keras. Nilai-nilai tersebut juga perlu di ejawantahkan dalam pembelajaran matematika. Sehingga 
peserta didik mampu menguasai ilmu matematika lebih dalam dan memiliki karakter yang baik.

Bentuk kontribusi etnomatematika pada proses produksi gula kelapa meliputi banyak hal. Diantaranya melalui identifikasi konsep-konsep matematika pada proses produksi gula kelapa diatas dapat memberikan pemahaman bahwa matematika teoritis dapat diterapkan dan dipelajari melalui aktivitas kehidupan dan kondisi sosial budaya di masyarakat. Juga dapat digunakan sebagai model pengembangan pembelajaran dan sumber materi sebagai bahan pembelajaran matematika. Selain itu juga dapat memanfaatan fenomena budaya kearifan lokal yang ada pada masyarakat dengan tujuan untuk mengenalkan konsep-konsep matematika yang kontekstual dengan kehidupan dan mengajarkan nilai-nilai karakter pada proses produksi gula kelapa.

\section{B. Pembahasan}

\section{Konsep Matematika pada Proses Produksi Gula Kelapa}

Berdasarkan hasil penelitian ini, diperoleh bahwa banyak sekali konsepkonsep matematika yang dapat dipelajari dan dikembangkan dari proses produksi gula kelapa. Aktivitas dan sarana prasarana pada proses produksi gula kelapa hampir seluruhnya berhubungan dengan matematika. Konsep-konsep yang teridentifikasi pada kegiatan produksi tersebut menunjukkan betapa pentingnya matematika dalam kehidupan manusia. Secara tidak langsung sebenarnya masyarakat khususnya pelaku usaha/produsen gula kelapa telah banyak mengaplikasikan teori dan konsep matematika. Meskipun secara mendalam mereka belum memahami keilmuan matematikanya.

Hal ini menunjukkan temuan bahwa pada konteks produksi gula kelapa fenomena etnomatematikanya dapat dijadikan sebagai sumber belajar matematika bagi siswa sekolah. Pembelajaranpun akan terasa lebih efektif dan bermakna karena kontekstual dengan aktivitas sehari-hari. Sejalan dengan hal tersebut, (Ubayanti, 2016) mengatakan bahwa melalui etnomatematika dapat diperoleh temuan potensi - potensi baru sebagai sarana pembelajaran matematika yang dapat menumbuhkan motivasi siswa dalam pembelajaran. 


\section{Histogram: Jurnal Pendidikan Matematika, 4 (1), 2020 - 173 \\ Mulyadi}

Adapun detail konsep-konsep matematika yang terdapat pada proses produksi gula kelapa di antaranya adalah konsep geometri bidang dan geometri ruang, konsep perbandingan, konsep jarak, waktu dan kecepatan, konsep pengukuran, konsep peluang, konsep aritmetika sosial, konsep kesebangunan dan matematika ekonomi. Temuan konsep pada proses produksi gula kelapa tersebut relevan jika diterapkan disekolah. Hal ini sesuai dengan hasil penelitian (Noto et al., 2018) yang menyatakan bahwa dalam pembelajaran matematika disekolah dapat menerapkan aspek-aspek matematika yang kontekstual dan dari hasil temuan ini tentunya dapat dijadikan sebagai sumber/media belajar siswa.

Penerapan konsep geometri ini dapat diterapkan dalam pembelajaran matematika di sekolah pada tingkatan tertentu. Seperti diungkapkan oleh (Ikhsan \& Juandi, 2015) bahwa pada pembelajaran geometri, khususnya di tingkat Sekolah Menengah Atas menitik beratkan pada materi dimensi tiga yang meliputi hubungan antara titik, garis, bidang dalam ruang dimensi tiga, dan berbagai hal yang muncul akibat adanya hubungan tersebut.

\section{Nilai-Nilai Karakter pada Proses Produksi Gula Kelapa}

Nilai-nilai yang terdapat dalam proses produksi gula kelapa antara lain adalah sabar, kerja keras, ketelatenan, dan semangat yang tinggi. Berdasarkan nilai-nilai tersebut dapat dijelaskan bahwa aktivitas yang berkaitan dengan proses produksi gula kelapa mengandung banyak makna serta nilai-nilai kearifan lokal yang perlu dipertahankan dan dikembangkan. Seperti pada proses penyadapan nira kelapa, dibutuhkan keterampilan serta keuletan. Selain itu pada saat pemasakan nira hingga menjadi gula kelapa memerlukan waktu yang cukup lama, sehingga diperlukan kesabaran, keterampilan, ketelatenan, serta semangat dalam menekuni usaha tersebut.

Mengajarkan nilai-nilai tersebut kepada siswa tanpa menunjukkan contoh atau bukti nyata kiranya lebih sulit dibandingkan dengan terjun ke lapangan dan mengamati langsung. Sehingga melalui konteks belajar ini diharapkan dapat memberikan pembelajaran langsung dan kontekstual yang memotivasi siswa untuk selalu berpegang teguh pada nilai-nilai karakter luhur dalam mempertahankan budaya kearifan lokal. 
Kajian tentang konteks proses produksi gula kelapa ini dapat dijadikan sarana melatih dan mengajarkan nilai-nilai karakter terhadap siswa. Diharapkan juga melalui studi etnomatematika pada proses produksi gula kelapa dapat memberikan inspirasi nilai-nilai karakter yang baik. Nilai-nilai tersebut dapat dikembangkan sebagai sarana pembentukan karakter siswa di sekolah. Hal ini juga diungkapkan oleh (Sutrisno, 2016) bahwa pendidikan nilai atau karakter merupakan salah satu komponen dalam pendidikan yang tidak hanya mendidik para peserta didiknya untuk menjadi manusia yang cerdas, tetapi juga membangun kepribadiannya agar memiliki akhlak yang mulia.

3. Kontribusi Etnomatematika pada Proses Poduksi Gula Kelapa Terhadap Pendidikan Matematika

Konsep matematika dan nilai-nilai karakter pada proses produksi gula kelapa dapat dijadikan sebagai sumber belajar dan menambah wawasan peserta didik mengenai aplikasi konsep matematika dalam kehidupan sehari-hari. Sesuai dengan hasil penelitian ini diperoleh data bahwa banyak konsep-konsep matematika yang teridentifikasi pada proses produksi gula kelapa. Artinya, etnomatematika pada proses produksi gula kelapa dapat dijadikan sebagai sumber pembelajaran matematika sekolah yang realistis dan kontekstual. (Noto et al., 2018) mengatakan bahwa pada proses pembelajaran matematika mentransformasi temuan etnomatematika dalam kehidupan sehari-hari dapat menambah wawasan siswa tentang keberadaan matematika pada unsur budaya, pemikiran matematis dan media untuk menghubungkan antara konsep matematika dengan realita dalam kehidupan nyata. Dengan demikian jelas bahwa etnomatematika memiliki kontribusi yang berarti bagi pendidikan matematika. Yakni memberikan pemahaman mengenai hubungan konsep-konsep matematika teoritis dengan kondisi sosial budaya di masyarakat, memanfaatkan konsep matematika pada proses produksi gula kelapa menjadi materi sebagai bahan pembelajaran matematika, memanfaatkan fenomena budaya kearifan lokal dengan tujuan untuk mengenalkan konsep-konsep matematika dan nilai-nilai pendidikan karakter. Selain itu (Arisetyawan et al., 2014) dan (Puspadewi, 2014) dalam hasil penelitiannya menyatakan bahwa penggunaan berbagai konsep matematika dalam 
konteks kehidupan nyata dapat menjadikan pembelajaran lebih kontekstual dan bermakna bagi peserta didik.

\section{KESIMPULAN DAN SARAN}

\section{A. Kesimpulan}

Berdasarkan hasil penelitian dan pembahasan di atas diperoleh kesimpulan beberapa hal. Pertama, terdapat konsep matematika pada proses produksi gula kelapa, antara lain konsep geometri bidang dan geometri ruang, konsep perbandingan, konsep jarak, waktu dan kecepatan, konsep pengukuran, konsep peluang, konsep aritmetika social, konsep kesebangunan dan matematika ekonomi. Kedua, terdapat nilai-nilai pada proses produksi gula kelapa, antara lain kesabaran, ketelatenan, keterampilan, kerja keras, dan semangat yang tinggi. Nilai-nilai tersebut dapat dikembangkan sebagai sarana pembentukan karakter siswa baik di sekolah maupun di masyarakat. Ketiga, Kontribusi nyata etnomatematika pada proses produksi gula kelapa memiliki peranan penting dalam pendidikan matematika. Diantaranya adalah memberikan wawasan kajian ilmu yang menghubungkan aplikasi konsep-konsep matematika teoritis dengan kondisi sosial budaya di masyarakat, pemanfaatan konsep matematika pada proses produksi gula kelapa menjadi materi dan bahan pembelajaran matematika, pemanfaatan fenomena budaya kearifan lokal dengan tujuan untuk mengenalkan konsep-konsep matematika dan pendidikan karakter.

\section{B. Saran}

Konsep-konsep matematika serta nilai-nilai karakter yang terdapat pada proses produksi gula kelapa dapat dijadikan sebagai sumber belajar maupun metode pembelajaran matematika kontekstual yang menyenangkan dan mudah dipahami.

\section{DAFTAR PUSTAKA}

Arisetyawan, A., Suryadi, D., Herman, T., \& Rahmat, C. (2014). Study Ethnomathematics: A Lesson of Baduy Culture. International Journal of Education and Research, 2(10), 681-688. 
Ikhsan, M., \& Juandi, D. (2015). Analisis Penguasaan Siswa Sekolah Menengah Atas pada Materi Geometri. Didaktik Matematika, 2(1), 64-70.

Mulyadi, \& Cahyani, D. N. A. (2017). Konsepsi Mahasiswa Pendidikan Matematika terhadap Mata Kuliah Metode Numerik. Jurnal Humaniora, $5(1), 652-656$.

Noto, M. S., Firmasari, S., \& Fatchurrohman, M. (2018). Etnomatematika pada sumur purbakala Desa Kaliwadas Cirebon dan kaitannya dengan pembelajaran matematika di sekolah Ethnomathematics at the sumur purbakala Kaliwadas Village of Cirebon and relationship with mathematics learning in school. 5(2), 201-210.

Nuh, Z. M., \& Dardiri. (2017). Etnomatematika Dalam Sistem Pembilangan Pada Masyarakat Melayu Riau. Kutubkhanah, 19(2), 220-238.

Puspadewi, K. R. (2014). Etnomatematika di Balik Kerajinan Anyaman Bali. Matematika, 4(2), 80-89.

Rachmawati, I. (2012). Eksplorasi Etnomatematika Masyarakat Sidoarjo. MATHEdunesa, 1(1), 1-8.

Sugiyono. (2014). Memahami Penelitian Kualitatif. Alfabeta.

Sutrisno. (2016). Berbagai Pendekatan dalam Pendidikan Nilai dan Pendidikan Kewarganegaraan. Jurnal Dimensi Pendidikan Dan Pembelajaran;, 5, 2637. https://doi.org/10.24269/dpp.v4i1.56

Ubayantii, C. et al. (2016). Eksplorasi Etnomatematika Pada Sero (Set-Net) : Budaya Masyarakat Kokas Fakfak Papua Barat. Jurnal Ilmiah Matematika Dan Pembelajarannya, 1(2007), 12-21.

Ubiratan D'ambrosio. (1985). FLM Publishing Association Ethnomathematics and Its Place in the History and Pedagogy of Mathematics. Source: For the Learning of Mathematics, 5(1), 44-48. 